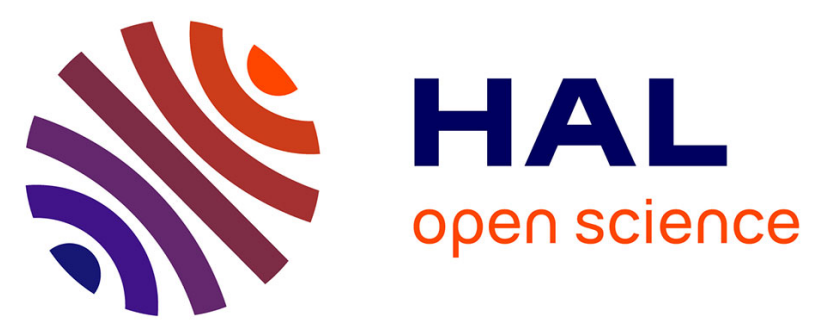

\title{
Formation of NDMA and Halogenated DBPs by Chloramination of Tertiary Amines: The Influence of Bromide Ion
}

Julien Le Roux, Hervé Gallard, Jean-Philippe Croué

\section{To cite this version:}

Julien Le Roux, Hervé Gallard, Jean-Philippe Croué. Formation of NDMA and Halogenated DBPs by Chloramination of Tertiary Amines: The Influence of Bromide Ion. Environmental Science and Technology, 2012, 46 (3), http://pubs.acs.org/doi/abs/10.1021/es203785s. 10.1021/es203785s . hal01201586

HAL Id: hal-01201586

https://hal-enpc.archives-ouvertes.fr/hal-01201586

Submitted on 17 Sep 2015

HAL is a multi-disciplinary open access archive for the deposit and dissemination of scientific research documents, whether they are published or not. The documents may come from teaching and research institutions in France or abroad, or from public or private research centers.
L'archive ouverte pluridisciplinaire HAL, est destinée au dépôt et à la diffusion de documents scientifiques de niveau recherche, publiés ou non, émanant des établissements d'enseignement et de recherche français ou étrangers, des laboratoires publics ou privés.

$$
\text { Copyright }
$$




\title{
Formation of NDMA and halogenated DBPs by
}

\section{chloramination of tertiary amines: the influence of}

\section{bromide ion}

\author{
JULIEN LE ROUX, HERVÉ GALLARD* AND JEAN-PHILIPPE CROUÉ 1
}

Laboratoire de Chimie et Microbiologie de l'Eau (CNRS UMR 6008), Université de Poitiers - ENSIP, 40 Avenue du Recteur Pineau, 86022 Poitiers Cedex, France

E-mail addresses: julien.leroux@univ-poitiers.fr (J. Le Roux), herve.gallard@univ-poitiers.fr (H. Gallard), jp.croue@kaust.edu.sa (J.P. Croué)

* Corresponding author phone: +33 (0)5 494544 31; fax: +33 (0)5 $4945 \quad 37$ 68; e-mail: herve.gallard@univ-poitiers.fr.

1 Current address: King Abdullah University of Science and Technology (KAUST), Thuwal 23955-6900, Kingdom of Saudi Arabia

\section{ABSTRACT}

The formation of NDMA and other DBPs (including THMs, HANs, HKs) has been investigated by chloramination of several tertiary amines in the absence and in the presence of bromide ion. NDMA formation from the most reactive tertiary amines (e.g. dimethylaminomethylfurfuryl alcohol or DMP30) was enhanced in the presence of bromide due to the formation of brominated oxidant species such as bromochloramine $(\mathrm{NHBrCl})$ and the hypothetical UDMH- $\mathrm{Br}$ as an intermediate. The formation of 
NDMA by chloramination of less reactive model compounds was inhibited in the presence of bromide.

This can be explained by competitive reactions leading to the production of brominated DBPs (i.e. THMs). In the presence of bromide, the formation of brominated THMs during chloramination can be attributed to the presence of small amounts of $\mathrm{HOBr}$ produced by the decomposition of chloramines and bromamines. The results are of particular interest to understand NDMA formation mechanisms, especially during chloramination of wastewaters impacted by anthropogenic tertiary amines and containing bromide ion.

\section{KEYWORDS}

NDMA, Nitrosamine, Chloramination, Disinfection By-products, THM, Bromide

\section{Introduction}

Chloramine disinfection is often used to reduce the formation of regulated disinfection by-products (DBPs), including trihalomethanes (THMs) and haloacetic acids (HAAs). Monochloramine is also used to avoid biofouling of reverse osmosis membranes in wastewater reclamation plants, but chloramination favors the formation of N-nitrosodimethylamine (NDMA), a probable human carcinogen (1). Over the last decade, formation mechanisms of NDMA during chloramination have been widely studied (2-4).

Proposed mechanisms for the formation of NDMA during chloramination generally involve a nucleophilic substitution between monochloramine $\left(\mathrm{NH}_{2} \mathrm{Cl}\right)$ and dimethylamine (DMA), forming an Unsymmetrical Dimethylhydrazine (UDMH) intermediate that is then rapidly oxidized to NDMA $(2,3)$. Schreiber \& Mitch (4) demonstrated the role of dichloramine $\left(\mathrm{NHCl}_{2}\right)$ and dissolved oxygen concentration during the formation of NDMA. Some tertiary amines presenting DMA functional groups have been shown to form significant amounts of $\operatorname{NDMA}(5,6)$. Some anthropogenic tertiary amines (i.e. pharmaceuticals or pesticides) have been shown to be significant NDMA precursors, which could explain NDMA yields observed in wastewater reclamation plants using chloramination. Especially, the pharmaceutical ranitidine (a histamine antagonist often used for peptic ulcer treatment) and other pharmaceutical compounds were found to generate significant amounts of NDMA (6-8). Ranitidine is 
characterized by its high molar conversion rate into NDMA (>60\%). 5-(dimethylaminomethyl)furfuryl alcohol (one of the compounds used for the production of ranitidine) has been shown to form as much NDMA as ranitidine (6), indicating that this structure would be responsible for the high yields observed with ranitidine.

Bromide ion is a frequent component of natural waters and wastewaters. Its concentration ranges from 0.05 to $0.3 \mathrm{mg} / \mathrm{L}$ in surface waters and wastewaters and is about $60 \mathrm{mg} / \mathrm{L}$ in seawater (9). Monochloramine is not stable and degrades rapidly when mixed with an excess of bromide (e.g. when seawater is chloraminated). Chloramines are known to oxidize bromide ions to form bromochloramine through a series of reactions (10), and the overall reaction is described as:

$$
2 \mathrm{NH}_{2} \mathrm{Cl}+\mathrm{H}^{+}+\mathrm{Br}^{-} \rightarrow \mathrm{NHBrCl}+\mathrm{NH}_{4}^{+}+\mathrm{Cl}^{-}
$$

Bromamines and bromochloramine $(\mathrm{NHBrCl})$ are less stable than chloramines. Especially, $\mathrm{NHBrCl}$ reacts with $\mathrm{NH}_{2} \mathrm{Cl}$ following equation 2 (11), explaining the catalytic role of bromide ion into the decomposition of $\mathrm{NH}_{2} \mathrm{Cl}$.

$$
\mathrm{NHBrCl}+\mathrm{NH}_{2} \mathrm{Cl} \rightarrow \mathrm{N}_{2}+\mathrm{Br}^{-}+2 \mathrm{Cl}^{-}+3 \mathrm{H}^{+}
$$

The chemistry of bromamines and chloramines are similar, and bromamines generally show a higher reactivity as compared to chloramines (12). As a result, it can be expected that bromamines react in the same manner than monochloramine to form NDMA via UDMH pathway (13). Few data are available regarding the direct reactivity of bromamines with organic compounds, but the disinfection of bromidecontaining waters using chlorine or chloramines has been widely studied and is known to form a variety of bromine-containing DBPs (14).

The formation of brominated species of THMs (e.g. bromoform), HAAs (bromoacetic acids), HANs (bromoacetonitriles), HNMs (e.g. tribromonitromethane or bromopicrin), bromopropanones or bromal hydrate has been reported during chlorination or chloramination of bromide-containing natural waters, and has been attributed to the formation of $\mathrm{HOBr}$, which is a more effective halogen-substituting agent than $\mathrm{HOCl}(14,15)$. Increasing bromide concentration increases the proportion of brominated THMs 
(16), HAAs (17), cyanogens halides (18), haloacetonitriles (HANs) (19) or halonitromethanes (HNMs)

(20), because bromine and chlorine are reacting in combination with similar sites.

Using chloramines instead of free chlorine in order to reduce the production of regulated DBPs may increase the formation of nitrogenous DBPs (N-DBPs) such as haloacetonitriles (HANs) or halonitromethanes (HNMs) (21). N-DBPs are known to be generally more toxic than regulated DBPs, and have been cited as research priorities by the U.S. EPA over the past few years $(22,23)$. In the presence of bromide, the formation of brominated species of N-DBPs is an important issue because of their potent health effects. Mutagenic and carcinogenic properties appear to increase with the degree of bromine substitution in DBPs (24). HNMs have been demonstrated to be particularly cytotoxic and genotoxic in mammalian cells, brominated species being more toxic than chlorinated compounds (25).

The influence of bromide ion on NDMA formation has been investigated during ozonation (26) and chlorination (27). NDMA formation during chlorination in the presence of bromide was proposed to occur through a bromine-enhanced nitrosation mechanism, similar to the free chlorine-enhanced nitrosation proposed by Choi \& Valentine (28). Chen et al. (27) also observed a clear increase in the formation of NDMA from DMA when bromide was present, but an inhibition of NDMA formation in the case of trimethylamine (TMA).

The aim of this study was to investigate the influence of bromide ion on the formation of NDMA by chloramination of several model compounds. Because tertiary amines can produce other DBPs than NDMA (i.e. halogenated and nitrogenous DBPs), THMs, HANs, HKs and TCNM were also monitored to compare the different reaction pathways. A variety of compounds were selected to investigate the influence of molecular structures. All of these compounds incorporate DMA functional groups substituted on aromatic or heterocyclic rings. Some of these structures (especially furan rings) have been proven to promote the formation of NDMA as compared to DMA (6).

\section{Materials and methods}

Materials. All experiments were conducted using deionized water (18.2 M $\Omega . c m$, Milli-Q, Millipore) buffered at $\mathrm{pH} 8$ with a mixture of sodium phosphate monobasic and sodium phosphate dibasic. 
Chemical structures of compounds investigated are summarized in Figure 1. All of these compounds were supplied through Sigma-Aldrich and were used without further purification. Standards solutions of trihalomethanes (100 $\mu \mathrm{g} / \mathrm{mL}$ each) and of haloacetonitriles (HANs), trichloronitromethane (TCNM) and haloketones (HKs) (EPA 551B Halogenated Volatiles Mix, $2000 \mu \mathrm{g} / \mathrm{mL}$ each) and internal standard 1,2-dibromopropane were supplied from Supelco. All other reagents were reagent grade or described previously (8). All glassware used during these experiments was washed with deionized water and baked at $500{ }^{\circ} \mathrm{C}$ for at least $5 \mathrm{~h}$ prior to use.<smiles>CN(C)Cc1ccc(CO)o1</smiles>

5-(dimethyl- aminomethyl) furfuryl alcohol

(DFUR)<smiles>CN(C)n1cccc1</smiles>

1-(dimethyl- amino) pyrrole

(DPYR)<smiles>CN(C)c1cccc(O)c1</smiles>

3-(dimethyl- amino) phenol (DPHE)<smiles>CN(C)Cc1cc(CN(C)C)c(O)c(CN(C)C)c1</smiles>

DMP30<smiles>CN(C)c1ccccn1</smiles>

2-(dimethyl- amino) pyridine

(DPYRI)<smiles>CN(C)c1ccc(N)cc1</smiles>

Dimethyl-4-phenylenediamine

(DMPD)

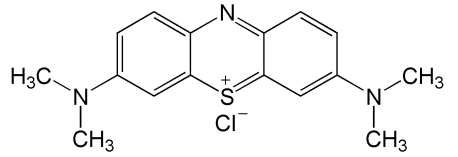

Methylene blue

(MB)<smiles>CNC</smiles>

Dimethylamine

(DMA)

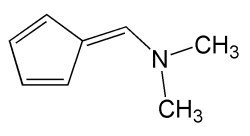

6-(dimethyl- amino) fulvene

(DFUL)

Figure 1. Molecular structure of the investigated compounds 
Chloramination experiments. Preparation of monochloramine and model compounds solutions was described previously (8). Experimental methods used during chloramination experiments and NDMA formation potentials determination were also described in a previous study (8) and followed the approach of Mitch et al. (29), using high concentrations of $\mathrm{NH}_{2} \mathrm{Cl}$ (200 to $300 \mathrm{mg} / \mathrm{L}$ as $\mathrm{Cl}_{2}$ ) and a reaction time of $24 \mathrm{~h}$ at $\mathrm{pH} 8$ for most of our experiments. $\mathrm{NH}_{2} \mathrm{Cl}$ remained in excess during all the reaction time. The concentration of organic compounds ranged from $250 \mathrm{nM}$ to $2 \mu \mathrm{M}$ depending on the experiment. At given contact times, $850 \mathrm{~mL}$ of samples were processed for nitrosamines analyses and $250 \mathrm{~mL}$ were transferred for residual chlorine and other DBPs analyses. Percent molar yields were calculated using the initial molar concentration of the studied compounds following equation 3 .

$$
\operatorname{DBP} \text { yield }(\%)=\frac{[\mathrm{DBP}](\mathrm{nM})}{[\text { Organic compound }]_{0}(\mathrm{nM})} \times 100
$$

For NDMA, formation yields were expressed as per mole of amine group, i.e. percent molar yield divided by the number of amine group present in the structure.

The bromine incorporation factor $\eta$ for THMs is defined as the following equation (30):

$$
\eta=\frac{\sum_{i=0}^{3} i \times\left[\mathrm{CHCl}_{3-i} \mathrm{Br}_{i}\right]}{\sum_{i=0}^{3}\left[\mathrm{CHCl}_{3-i} \mathrm{Br}_{i}\right]}
$$

where $i$ equals the number of bromine atoms in a particular THM molecule. The value of $\eta$ ranges between 0 (all chloroform) and 3 (all bromoform).

Analyses. Free chlorine and total chlorine concentrations in the stock solutions of sodium hypochlorite were determined by iodometric titration with sodium thiosulfate $0.1 \mathrm{M}$ (Prolabo, $>99.9 \%$ ). $\mathrm{NH}_{2} \mathrm{Cl}$ and $\mathrm{NHCl}_{2}$ concentrations were determined in reaction vessels by spectrophotometric measurement using their respective molar extinction coefficients at $245 \mathrm{~nm}$ and $295 \mathrm{~nm}$ and solving simultaneous equations (31). $\mathrm{NHBrCl}$ was quantified using its molar absorptivity at $220 \mathrm{~nm}(10)$. Organic compounds were verified not to interfere with the determination of the haloamines content in 
our experimental conditions (i.e. in large excess of $\mathrm{NH}_{2} \mathrm{Cl}$ ). Residual oxidant was analyzed by iodometry (32). This method takes into account every oxidizing species containing chlorine $(\mathrm{Cl}[+\mathrm{I}]$, i.e. free chlorine and chloramines) or bromine $(\mathrm{Br}[+\mathrm{I}]$, i.e. free bromine and bromamines). Chloramination reactions were quenched using a slight excess of sodium thiosulfate $(2 \mathrm{~g} / \mathrm{L})$ prior to NDMA and halogenated DBPs analyses. NDMA was analyzed following EPA method 521 by GC/MS (33). Analytical details were provided elsewhere (34) and are summarized in Supporting Information (SI). THMs, HANs, HKs and TCNM analysis was based on the US EPA 551.1 method (see SI).

\section{Results and discussion}

$\mathbf{N H}_{2} \mathrm{Cl}$ decomposition modeling. The decomposition of monochloramine was investigated at $\mathrm{pH} 8$ and $20{ }^{\circ} \mathrm{C}$ in the presence and in the absence of bromide with the objective to verify that the decay of total oxidant follows monochloramine self-disproportionation and bromide oxidation during our experimental conditions ( $\mathrm{pH} \mathrm{8,10} \mathrm{mM} \mathrm{phosphate} \mathrm{buffer).} \mathrm{Residual} \mathrm{oxidant} \mathrm{after} 24 \mathrm{~h}$ in the presence of $1 \mathrm{mM}$ bromide was notably decreased as compared to solutions without $\mathrm{Br}^{-}$(Figure 2). In the absence of bromide, kinetic modeling performed using Copasi software and Jafvert and Valentine's model (35) predicted well our experimental data and confirmed that monochloramine predominantly decays by selfdecomposition under our experimental conditions. Based on rate coefficients obtained from previous studies $(10,12,36)$, Vikesland et al. (11) proposed a kinetic model describing the decomposition of $\mathrm{NH}_{2} \mathrm{Cl}$ in the presence of bromide. Reactions and corresponding rate coefficients were included in the monochloramine decay model (Table SI-1). This model fitted our experimental results only in the first 2 hours of contact time, but it overestimated the decomposition of $\mathrm{NH}_{2} \mathrm{Cl}$ after 2 hours (Figure 2).

Trofe et al. (10) demonstrated that monobromamine $\left(\mathrm{NH}_{2} \mathrm{Br}\right)$ and dibromamine $\left(\mathrm{NHBr}_{2}\right)$ formation is not likely to be observed during $\mathrm{NH}_{2} \mathrm{Cl}$ decomposition in the presence of bromide, and that $\mathrm{NHBrCl}$ is the main species formed. The first step of monochloramine decomposition is probably the oxidation of bromide ion by $\mathrm{NH}_{2} \mathrm{Cl}$ to form $\mathrm{NH}_{2} \mathrm{Br}$ or $\mathrm{NH}_{3} \mathrm{Br}^{+}$(Equations 5 and 6). These species react rapidly to form $\mathrm{NHBrCl}$ according to equation 7. 
$\mathrm{NH}_{2} \mathrm{Cl}+\mathrm{H}^{+}=\mathrm{NH}_{3} \mathrm{Cl}^{+}$

$\mathrm{NH}_{3} \mathrm{Cl}^{+}+\mathrm{Br}^{-} \rightarrow \mathrm{NH}_{3} \mathrm{Br}^{+}+\mathrm{Cl}^{-}$

$\mathrm{NH}_{3} \mathrm{Br}^{+}+\mathrm{NH}_{2} \mathrm{Cl} \rightarrow \mathrm{NHBrCl}+\mathrm{NH}_{4}^{+}$

The kinetic model proposed by Vikesland et al. (11) only describes $\mathrm{NH}_{2} \mathrm{Cl}$ decomposition but does not take into account the production of $\mathrm{NHBrCl}$ (see SI). In our work, $\mathrm{NHBrCl}$ concentrations determined by using its absorptivity at $220 \mathrm{~nm}$ reached $0.16 \mathrm{mM}$ after $12 \mathrm{~h}$ and then slowly decreased with time. The presence of $\mathrm{NHBrCl}$ in solution should be detected during iodometric titration, which could explain why observed values were higher than the simulated curve. $\mathrm{NHBrCl}$ concentration values were taken into account to adjust the model. The corrected results were closer to residual oxidant values measured by iodometry, especially at the end of the experimental contact time (Figure 2); however, measured values between $2 \mathrm{~h}$ and $20 \mathrm{~h}$ of contact time were still a bit higher than the corrected model. This difference could be explained by the presence of other oxidizing species formed during $\mathrm{NH}_{2} \mathrm{Cl}$ decomposition in the presence of bromide. Small amounts of bromamines species such as $\mathrm{NBrCl}^{-}, \mathrm{NHBr}_{2}, \mathrm{NBr}_{2}^{-}$or $\mathrm{NH}_{2} \mathrm{Br}$ are likely to be formed in our experimental conditions (12). All of these species are thus expected to account for a part of the residual oxidant measured by iodometric titration.

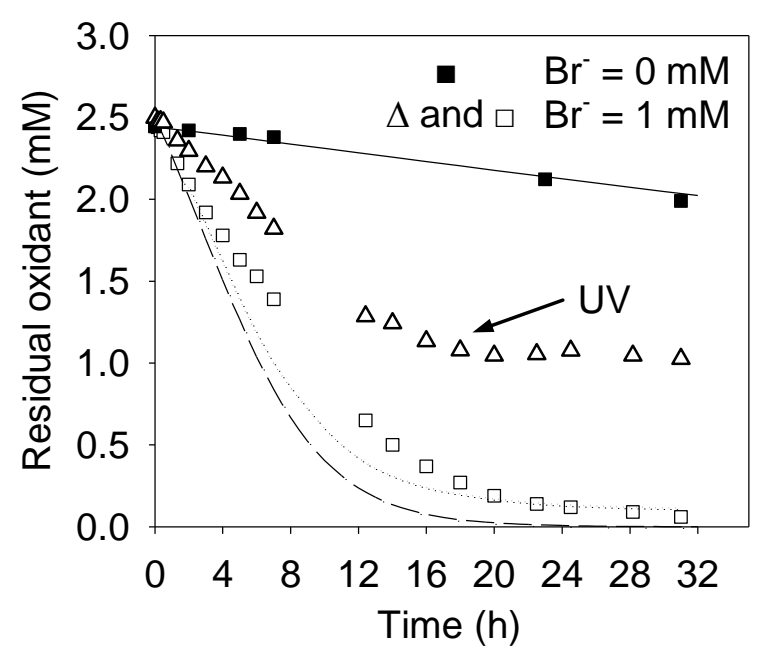

Figure 2. Effect of $1 \mathrm{mM}$ bromide ion on the decomposition of $2.5 \mathrm{mM} \mathrm{NH}_{2} \mathrm{Cl}$ at $20{ }^{\circ} \mathrm{C}$ and $\mathrm{pH} 8$. Symbols are experimental data and lines represent the simulated residual oxidant following Jafvert \& Valentine (35) and Vikesland et al. (11) kinetic models. Square values are measured by iodometric 
titration and triangles represent values calculated by spectrophotometry. Dotted line represents model values taking into account $\mathrm{NHBrCl}$ values.

During decomposition of $2.5 \mathrm{mM} \mathrm{NH}_{2} \mathrm{Cl}$ in the presence of $1 \mathrm{mM}$ bromide ion, residual oxidant measured by iodometric titration and values obtained by UV spectrophotometry exhibited a large difference increasing with reaction time (Figure 2). This interference can be attributed to the formation of an unknown product, which presents a strong absorbance at $245 \mathrm{~nm}$, but does not oxidize $\mathrm{I}^{-}$ions during iodometric titration (see SI). This product accumulated during the reaction while residual oxidant almost completely disappeared after $24 \mathrm{~h}$ of contact time. The formation of such a product has already been reported during the decomposition of chloramines in the absence of bromide, but the product remains unidentified (37).

NDMA formation. Experiments were carried out to investigate the potential role of bromide ion on the formation of NDMA by chloramination of model compounds. Solutions of nitrogenous compounds were prepared with or without bromide $(1 \mathrm{mM})$ and were chloraminated with $2.5 \mathrm{mM} \mathrm{NH}_{2} \mathrm{Cl}$ in the same conditions than described before ( $24 \mathrm{~h}$ contact time, $\mathrm{pH} 8$ with phosphate buffer). Similar oxidant consumptions were observed in the absence and in the presence of organic compounds. Because concentrations of the investigated compounds were low as compared to those of $\mathrm{NH}_{2} \mathrm{Cl}$ and bromide, $\mathrm{NH}_{2} \mathrm{Cl}$ mainly decomposed by self-disproportionation and bromide oxidation. Therefore, the consumption of $\mathrm{NH}_{2} \mathrm{Cl}$ by organic compounds could not be quantified.

From the pool of compounds studied, DFUR exhibited the highest production of NDMA in the absence of bromide $(74.9 \%)$ (Table 1$)$. This structure is known to be an important NDMA precursor, as well as the pharmaceutical ranitidine (6). DMP30 led to $18.4 \%$ yields of NDMA per mole of amine group (55.2\% yield per molecule) (Table 1). The structural reason explaining the high yields observed for DFUR and DMP30 is the presence of a carbon atom between the DMA group and the cyclic ring. Initial results indicate that the presence of this carbon atom promotes the release of UDMH, the intermediate involved in NDMA formation mechanisms. The other compounds investigated formed less 
than $2 \%$ of NDMA as molar yields, even less than DMA (2.3\%). According to Mitch \& Schreiber (38), the formation of NDMA from tertiary alkylamines involves an initial step of degradation into secondary amines, which can then react with chloramines through the UDMH pathway. This supplementary step could explain why several tertiary amines compounds formed less NDMA than DMA did.

The presence of $1 \mathrm{mM}$ bromide inhibited the formation of NDMA from the least reactive investigated compounds (Table 1). In the presence of bromide, almost no NDMA was detected after chloramination of DFUL and DPYRI, the two compounds that produced the smallest amounts of NDMA in the absence of bromide.

Table 1. Influence of bromide ion on NDMA formation from selected compounds (500 nM), with 2.5 $\mathrm{mM} \mathrm{NH}_{2} \mathrm{Cl}$ after $24 \mathrm{~h}$ of contact time at $\mathrm{pH} 8$ with $10 \mathrm{mM}$ phosphate buffer.

\begin{tabular}{|c|c|c|c|c|}
\hline \multirow[t]{2}{*}{ Compound } & \multicolumn{4}{|c|}{ NDMA yield $\left(\% \%^{a}\right)\left(S^{b}\right)$} \\
\hline & \multicolumn{2}{|c|}{ Without $\mathrm{Br}^{-}$} & \multicolumn{2}{|c|}{ With $1 \mathrm{mM} \mathrm{Br}^{-}$} \\
\hline DFUR & 74.9 & $( \pm 3.5)$ & 90.3 & $( \pm 2.6)$ \\
\hline DMP30 & 18.4 & $( \pm 5.4)$ & 23.9 & $( \pm 0.1)$ \\
\hline DMA & 2.3 & $( \pm 0.2)$ & 4.0 & $( \pm 0.2)$ \\
\hline DPYR & 1.6 & $( \pm 0.1)$ & 0.5 & $( \pm 0.1)$ \\
\hline $\mathrm{MB}$ & 0.8 & $( \pm 0.1)$ & 0.8 & $( \pm 0.1)$ \\
\hline DPHE & 1.0 & $( \pm 0.1)$ & 0.9 & $( \pm 0.1)$ \\
\hline DMPD & 0.9 & $( \pm 0.1)$ & 1.9 & $( \pm 0.1)$ \\
\hline DFUL & 0.53 & $( \pm 0.07)$ & 0.02 & $( \pm 0.01)$ \\
\hline DPYRI & 0.37 & $( \pm 0.01)$ & 0.03 & $( \pm 0.01)$ \\
\hline \multicolumn{5}{|c|}{${ }^{a}$ Yield per mole of amine group } \\
\hline \multicolumn{5}{|c|}{ b $\mathrm{SD}=$ Standard Deviation on 3 replicates } \\
\hline $\begin{array}{l}\text { Bold and } \\
\text { increase or } \\
\text { respectively }\end{array}$ & $\begin{array}{l}\text { italici } \\
\text { a dec }\end{array}$ & $\begin{array}{l}\text { d numb } \\
\text { ase in } N\end{array}$ & $\begin{array}{l}\text { rs ir } \\
\text { OMA }\end{array}$ & $\begin{array}{l}\text { icate an } \\
\text { ormation, }\end{array}$ \\
\hline
\end{tabular}


On the contrary, the presence of bromide was found to significantly enhance the formation of NDMA during the chloramination $\left(2.5 \mathrm{mM} \mathrm{NH}_{2} \mathrm{Cl}\right)$ of DMPD, dimethylamine, DMP30 and DFUR (Table 1). NDMA formation from DMA and DMPD was almost doubled, and increased by $14 \%$ and $17 \%$ for DFUR and DMP30, respectively. Figure 3a depicts the influence of bromide concentration on the formation of NDMA by chloramination $(2.5 \mathrm{mM})$ of $250 \mathrm{nM}$ DFUR during $24 \mathrm{~h}$ at $\mathrm{pH} 8$. Molar yield of NDMA formation increased from $79 \%$ to $89 \%$ with increasing bromide concentration. NDMA formation also increased from $2.3 \%$ to $3.6 \%$ during the chloramination of DMA at different bromide concentrations (Figure 4). The presence of significant amount of $\mathrm{NHBrCl}$ was detected at $24 \mathrm{~h}$ of contact time by measuring its absorbance at $220 \mathrm{~nm}$ (Figure 3a). Residual oxidant after $24 \mathrm{~h}$ was decreased when bromide concentration increased, and almost no residual was observed at bromide concentrations greater than $1 \mathrm{mM}$. Even if the presence of bromide favors the decomposition of total oxidant, the formation of bromamine species such as $\mathrm{NHBrCl}$ is likely to enhance the formation of NDMA. $\mathrm{NHBrCl}$ is expected to produce more NDMA than $\mathrm{NH}_{2} \mathrm{Cl}$ due to the higher electronegativity of the brominated nitrogen atom, thus favoring the nucleophilic substitution with DMA.

The formation of the unknown product described earlier is unlikely to be involved in the formation of NDMA because of its low oxidizing power, as it does not oxidize $\mathrm{I}^{-}$ions during the iodometric titration. $\mathrm{NH}_{2} \mathrm{Cl}$ residual calculated with Jafvert \& Valentine (35) and Vikesland et al. (11) kinetic models predicted well our experimental data at bromide concentrations lower than $0.2 \mathrm{mM}(16 \mathrm{mg} / \mathrm{L})$ but slightly overestimated oxidant decomposition for higher bromide concentrations (Figure 3a). Other oxidant species than $\mathrm{NH}_{2} \mathrm{Cl}$ may be formed at these concentrations (e.g. $\mathrm{NHBrCl}$ ), but they are not taken into account in these kinetic models. It should be noticed that the formation of the unknown product may interfere with $\mathrm{NHBrCl}$ determination using its absorbance at $220 \mathrm{~nm}$. 


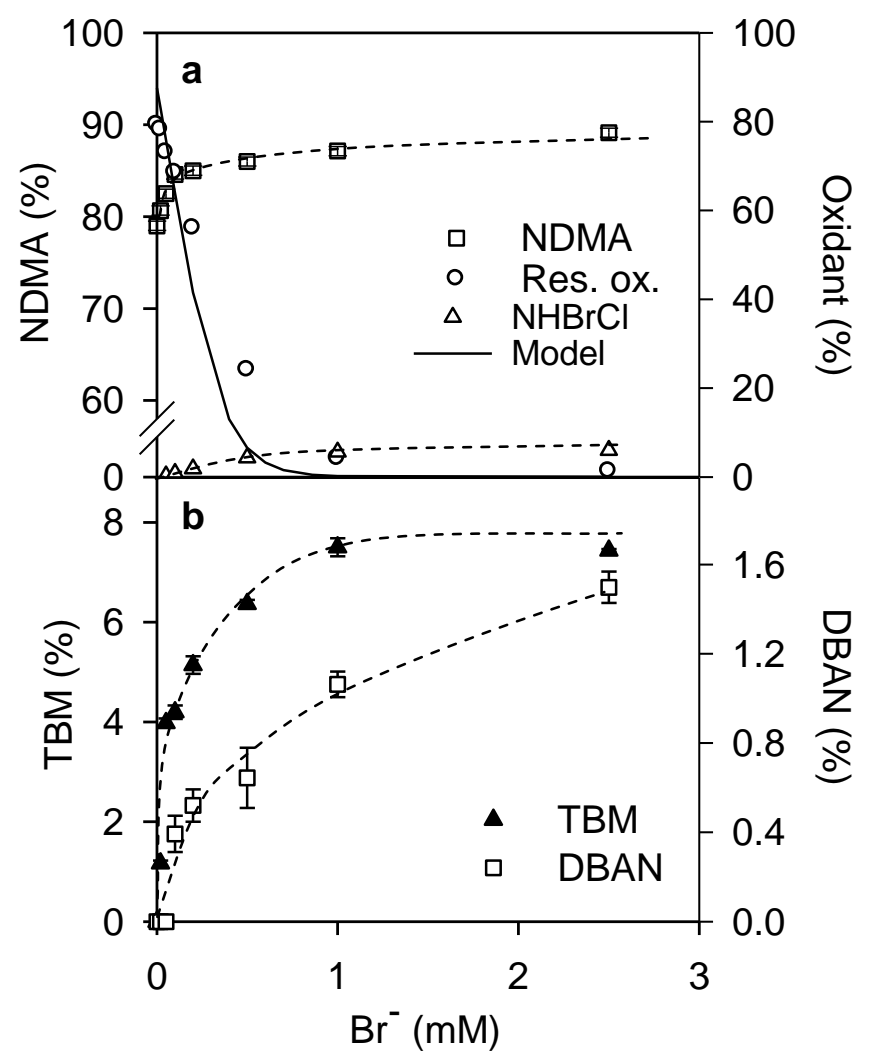

Figure 3. Influence of bromide concentration on a) NDMA formation, measured residual oxidant and simulated residual oxidant; and b) DBAN and TBM formation from $250 \mathrm{nM}$ DFUR and $2.5 \mathrm{mM} \mathrm{NH}_{2} \mathrm{Cl}$, over $24 \mathrm{~h}$ at $\mathrm{pH} 8$ with $10 \mathrm{mM}$ phosphate buffer. Dashed lines represent best fits of data.

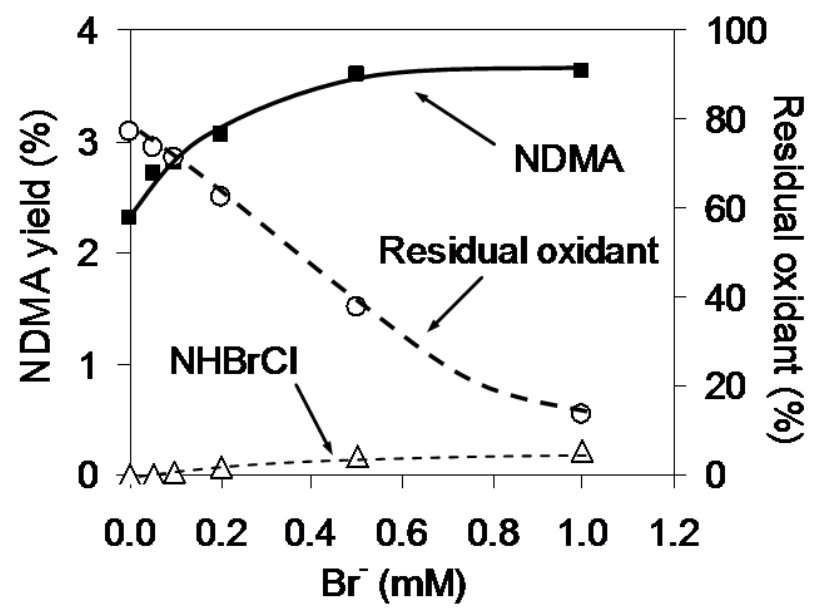

Figure 4. Influence of bromide concentration on NDMA formation from $2 \mu \mathrm{M}$ DMA and $2.5 \mathrm{mM}$ $\mathrm{NH}_{2} \mathrm{Cl}$ after $24 \mathrm{~h}$ of contact time at $\mathrm{pH} 8$ with $10 \mathrm{mM}$ phosphate buffer. Dashed lines represent residual oxidant and $\mathrm{NHBrCl}$ concentrations. 
HANs, HKs, TCNM and THMs formation. Table 2 and Table 3 summarize the formation of halogenated DBPs (HANs, HKs, TCNM, THMs) during the chloramination of several compounds. HANs and TCNM were monitored to compare the formation of NDMA with the formation of some other nitrogenous DBPs. Model compounds that do not appear in Table 2 and Table 3 did not lead to detectable amounts of DBPs after $24 \mathrm{~h}$ of contact time. TCAN and 1,1,1-TCP were not detected after chloramination of the model compounds in our experimental conditions.

Few model compounds formed significant amounts of DBPs in the absence of bromide. Only DMA and DPHE produced chloroform, $1.4 \%$ and 21.4\%, respectively (Table 2). DFUL led to substantial amounts of TCNM, 1,1-DCP and DCAN, while other compounds investigated formed much less DBPs (i.e. $<1 \%$ when detected).

The proportion of bromine-containing THMs (i.e. DCBM, CDBM and TBM) increased as expected when $1 \mathrm{mM}$ of bromide was added (Table 2). Interestingly, the bromine incorporation factor ( $\eta$ ) was quite similar for each compound studied $(\eta=2.88 \pm 0.05)$. For THMs, $\eta$ values close to 3 indicate that bromoform (TBM) tends to form preferentially. Hence, DBPs containing more bromine atoms (i.e. TBM $>\mathrm{CDBM}>\mathrm{DCBM}$ ) were formed in higher amounts after $24 \mathrm{~h}$ of contact time, indicating that the incorporation of bromine into DBPs is easier than chlorine, probably because of the higher reactivity of bromine-containing oxidant species. When bromide was added, most model compounds formed substantial amounts of bromine-containing THMs while they did not lead to significant amounts of TCM in the absence of bromide (e.g. DPYR, DPYRI and DFUL). This finding supports the fact that bromine-containing oxidants $(\mathrm{HOBr}, \mathrm{NHBrCl}$ or other bromamines) are more reactive than chloramines. Similar observations were reported by chlorination of humic or fulvic acid in the presence of bromide $(17,18,39)$. The higher yields of total THMs were attributed to the production of $\mathrm{HOBr}$ that exerts stronger substitution reactivity than $\mathrm{HOCl}$. Only few studies investigated the reactions between organic compounds and bromamines. It was suggested that the formation of $\mathrm{NHBrCl}$ was responsible for the formation of brominated DBPs, especially cyanogen bromide $(\mathrm{CNBr})(16,40)$. 
For DPHE the production yield of TBM was $21.2 \%$ in the presence of bromide, similar to the value obtained for the formation of TCM in the absence of bromide. Resorcinol is known to be an important precursor of THMs by chlorination ( $\sim 90-95 \%$ yields) and chloramination $(<8 \%$ yields) $(41)$. In the case of DPHE, the presence of a DMA substituent, a stronger electron-donating group than hydroxyl (known to activate the benzene ring for electrophilic aromatic substitution) can explain the higher TCM and TBM yields observed as compared to resorcinol.

HANs formation did not exhibit the same trends as THMs formation did. In most cases, the presence of $1 \mathrm{mM} \mathrm{Br}-$ inhibited the formation of HANs. Only DPYR formed significant amounts of DBAN (25.5\% yield) and BCAN (4.3\%). DFUR also formed a small amount of DBAN (i.e. 0.7\% yield). For these two compounds the presence of bromide shifted the DBP species into brominated species: DCAN and 1,1-DCP could not be detected but DBAN and BCAN were formed. Other compounds investigated did not form any HANs, 1,1-DCP or TCNM in the presence of bromide. Bromo-2-propanone, 1-bromo1-chloropropanone and dibromopropanone were also detected in full scan mode for DPYR. Unfortunately, these bromine-containing haloketones or halonitromethane (e.g. dibromonitromethane) could not be quantified due to the lack of analytical standards.

In the absence of bromide, compounds which formed substantial amounts of halogenated DBPs (i.e. DFUL, DPYRI) are weak precursors of NDMA (Table 1). On the contrary, compounds exhibiting the highest NDMA yields (i.e. DFUR, DMP30, DMA) were amongst the lowest precursors of HANs or THMs, especially when bromide was present. As a result, an enhanced reactivity of some tertiary amines leading to more THMs, HANs or other DBPs could induce competitive reactions leading to a decrease in NDMA formation. In the case of other weak precursors of NDMA (i.e. DMPD, MB), no detectable amounts of halogenated DBPs were observed. The presence of bromide did not inhibit NDMA formation from these precursors (Table 1). The low reactivity of these compounds towards the formation of brominated DBPs seems to indicate that minor competitive halogenated reactions would occur concurrently with the formation of NDMA. 
Table 2. Influence of bromide ion on THMs formation by chloramination $\left(2.5 \mathrm{mM} \mathrm{NH}_{2} \mathrm{Cl}\right)$ of selected compounds $(500 \mathrm{nM})$ at $\mathrm{pH} 8$ during $24 \mathrm{~h}$ of contact time.

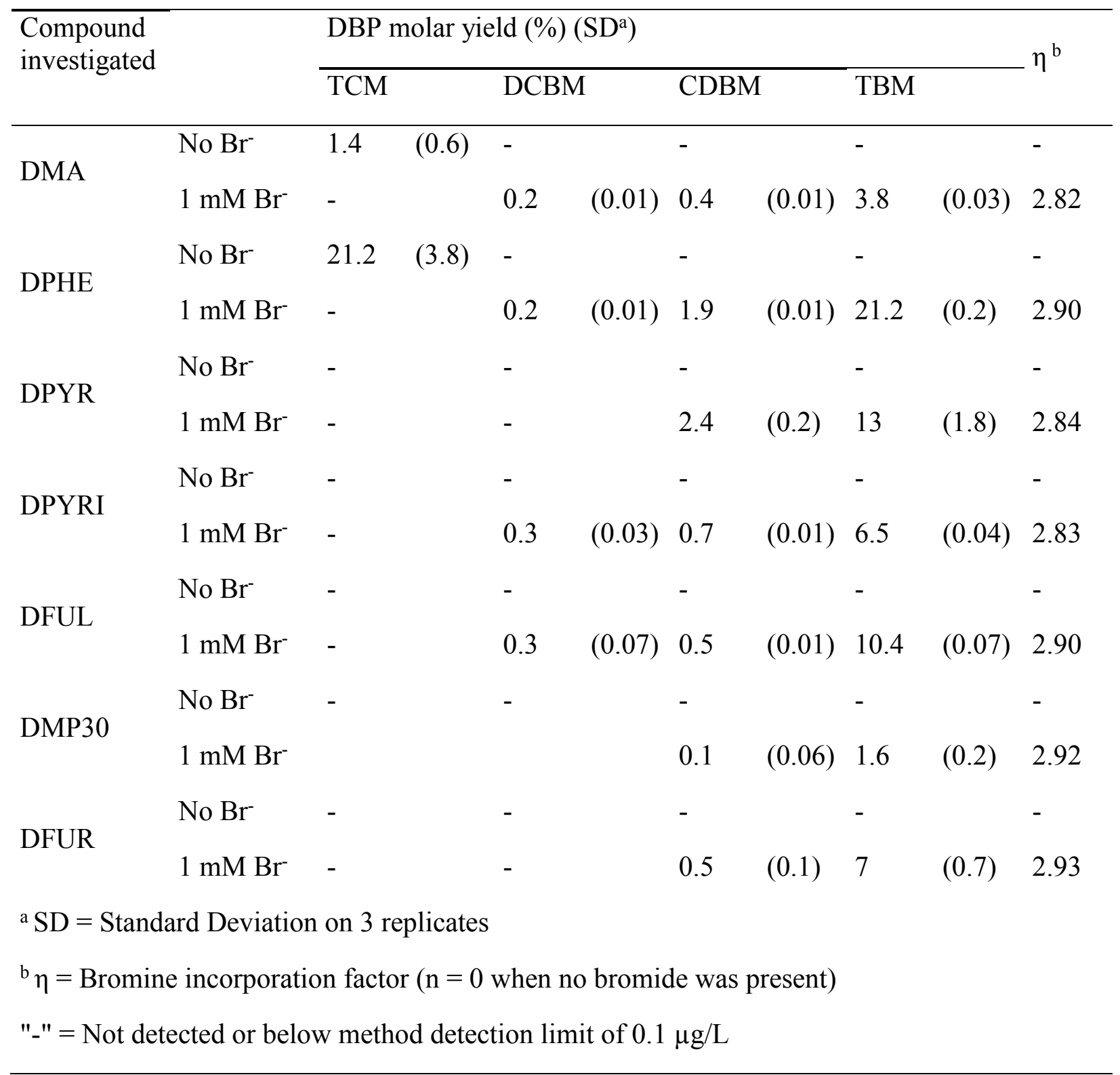


Table 3. Influence of bromide ion on selected DBPs formation from model compounds (500 nM) with $2.5 \mathrm{mM} \mathrm{NH}_{2} \mathrm{Cl}$ at $\mathrm{pH} 8$ during $24 \mathrm{~h}$ of contact time.

\begin{tabular}{|c|c|c|c|c|c|c|c|c|c|c|}
\hline \multirow{3}{*}{$\begin{array}{l}\text { Compound } \\
\text { investigated } \\
\text { DFUL }\end{array}$} & & \multicolumn{9}{|c|}{ DBP molar yield $(\%)\left(\mathrm{SD}^{\mathrm{a}}\right)$} \\
\hline & & \multirow{2}{*}{\begin{tabular}{ll}
\multicolumn{2}{l}{ TCNM } \\
$2.1 \quad(0.5)$
\end{tabular}} & \multicolumn{2}{|c|}{$1,1-\mathrm{DCP}$} & \multicolumn{2}{|c|}{ DCAN } & \multicolumn{2}{|c|}{ DBAN } & \multicolumn{2}{|c|}{ BCAN } \\
\hline & $\mathrm{No} \mathrm{Br}^{-}$ & & 8.9 & $(0.7)$ & 2.9 & $(0.6)$ & - & & - & \\
\hline & $1 \mathrm{mM} \mathrm{Br}-$ & - & - & & - & & - & & - & \\
\hline DPYRI & No $\mathrm{Br}^{-}$ & $0.13(0.02)$ & 0.7 & $(0.02)$ & 0.7 & $(0.1)$ & - & & - & \\
\hline & $1 \mathrm{mM} \mathrm{Br}$ & - & - & & - & & - & & - & \\
\hline DPYR & No $\mathrm{Br}^{-}$ & $0.32(0.04)$ & 0.2 & $(0.1)$ & 1.2 & $(0.2)$ & - & & - & \\
\hline & $1 \mathrm{mM} \mathrm{Br}-$ & - & - & & - & & 25.5 & $(0.5)$ & 4.3 & $(2.7)$ \\
\hline DFUR & No $\mathrm{Br}^{-}$ & - & 0.2 & $(0.02)$ & 0.7 & $(0.2)$ & - & & - & \\
\hline & $1 \mathrm{mM} \mathrm{Br}-$ & - & - & & - & & 0.7 & $(0.2)$ & 0.07 & $(0.01)$ \\
\hline
\end{tabular}

Influence of bromide concentration. The influence of bromide concentration was studied during chloramination of DFUR. The production of bromoform (TBM) and DBAN from the reaction of DFUR (250 nM) with $2.5 \mathrm{mM} \mathrm{NH} 2 \mathrm{Cl}$ increased with increasing bromide concentration (Figure 3b). TBM formation reached a plateau at bromide concentration greater than $1 \mathrm{mM}$, i.e. for a $\mathrm{Br}: \mathrm{Cl}$ molar ratio greater than 0.4. DBAN formed in lower amounts than TBM and continue to increase as bromide concentration increased. These results can be related to a higher reactivity of DFUR towards the formation of THMs than that of HANs. This is in accordance with results of DBPs formation by chlorination of proteins, exhibiting a two-step process (42). First, rapid reactions with reactive sites form THMs and Total Organic Halides (TOX) (43), then slow degradation of proteins leads to DCAN formation. A similar reaction mechanism could occur during the chloramination of DFUR in the presence of bromide. 
Proposed formation mechanisms. Our results suggest that bromine-containing oxidant species can enhance the formation of NDMA from some tertiary amines or DMA. Possible reaction pathways are summarized in Scheme 1. As proposed by Chen et al. (27), DMA could react with $\mathrm{NHBrCl}$ (or $\mathrm{NHBr}_{2}$ eventually) to form an hypothetical UDMH-Br similar to the formation of UDMH-Cl from $\mathrm{NHCl}_{2}$. Subsequent oxidation of UDMH-Br in the presence of dissolved oxygen would then lead to NDMA and other degradation products such as dimethylcyanamide (DMC) or dimethylformamide (DMF) $(3,4)$. The larger amounts of NDMA formed can be explained by the higher reactivity of $\mathrm{NHBrCl}$ than $\mathrm{NH}_{2} \mathrm{Cl}$ or $\mathrm{NHCl}_{2}$, leading to increased amounts of the UDMH-Br intermediate as compared to UDMH. UMDH-Cl has been suggested to favor the incorporation of dissolved $\mathrm{O}_{2}$ as compared to UDMH because of the weakness of the $\mathrm{N}-\mathrm{Cl}$ bond (4). In a similar manner, a weaker $\mathrm{N}-\mathrm{Br}$ bond in UDMH-Br could also produce NDMA more easily.

Choi \& Valentine (2) suggested that the formation of chlorinated DMA (CDMA) by chlorine transfer between $\mathrm{NH}_{2} \mathrm{Cl}$ and DMA could contribute to reduce NDMA formation. In the presence of bromide, the formation of similar brominated DMA could also play a role in the reduction of the amounts of NDMA formed. Formation mechanisms remain however unclear for tertiary amines (especially ranitidine, DFUR or DMP30) leading to high yields of NDMA ( $>50 \%)$. The importance of molecular structures such as furan rings substituted with DMA groups has been pointed out $(6,8)$. It can be hypothesized that such structures will not lead to the formation of CDMA, thus favoring the formation of important amounts of NDMA. Further research is needed to investigate NDMA formation mechanisms by chloramination of tertiary amines.

The inhibition of NDMA formation observed for some compounds (i.e. DFUL, DPYR, DPYRI, DPHE) could be related to the formation of other DBPs (especially THMs), competing with the formation of NDMA. Auto-decomposition of chloramines leads to the formation of small amounts of $\mathrm{HOCl}$ through the hydrolysis of $\mathrm{NH}_{2} \mathrm{Cl}$, according to equation 8 (35).

$$
\mathrm{NH}_{2} \mathrm{Cl}+\mathrm{H}_{2} \mathrm{O} \rightarrow \mathrm{HOCl}+\mathrm{NH}_{3}
$$


Kinetic modeling performed using Jafvert \& Valentine's model (35) demonstrated that the selfdecomposition of $2.5 \mathrm{mM} \mathrm{NH}_{2} \mathrm{Cl}$ could form up to $10 \mathrm{nM} \mathrm{HOCl}$ in the first minutes of reaction at $\mathrm{pH} 8$. These small amounts of $\mathrm{HOCl}$ would react rapidly with bromide ion (in excess in our experimental conditions) to form $\mathrm{HOBr}$. Cimetiere et al. (41) demonstrated that the presence of low concentrations of $\mathrm{HOCl}$ produced by $\mathrm{NH}_{2} \mathrm{Cl}$ hydrolysis could be largely responsible for the formation of TCM during chloramination of resorcinol. In a similar way, $\mathrm{HOBr}$ could be responsible for the formation of brominecontaining THMs. $\mathrm{HOBr}$ is known to be more reactive than $\mathrm{HOCl}$ toward phenolic compounds (44). Therefore, $\mathrm{HOBr}$ formation could explain that more bromine-containing THMs were formed after $24 \mathrm{~h}$ of contact time, while less TCM was formed in the absence of bromide.

Our results demonstrate the formation of THMs during chloramination of DMA, especially in the presence of bromide (Table 2). Chlorination or chloramination of DMA is well documented. Major products of the chlorination or chloramination of DMA consist in chlorodimethylamine (CDMA) (45), NDMA, DMC and DMF (3). Few studies, however, reported the formation of THMs during oxidation reactions of DMA. CDMA is produced by chlorine transfer between $\mathrm{HOCl}$ or $\mathrm{NH}_{2} \mathrm{Cl}$ and protonated DMA (pH below 7) (3). Our results show with evidence the reaction between free chlorine and methyl groups from alkylamines. Yang \& Shang (18) have reported the formation of chloroform by chlorination of methylamine and diethylamine. More recently, Chang et al. (46) observed the formation of THMs and HAAs by chlorination and chloramination of DMA and other amine-based compounds, but those studies did not provide any formation mechanisms related to their findings. 


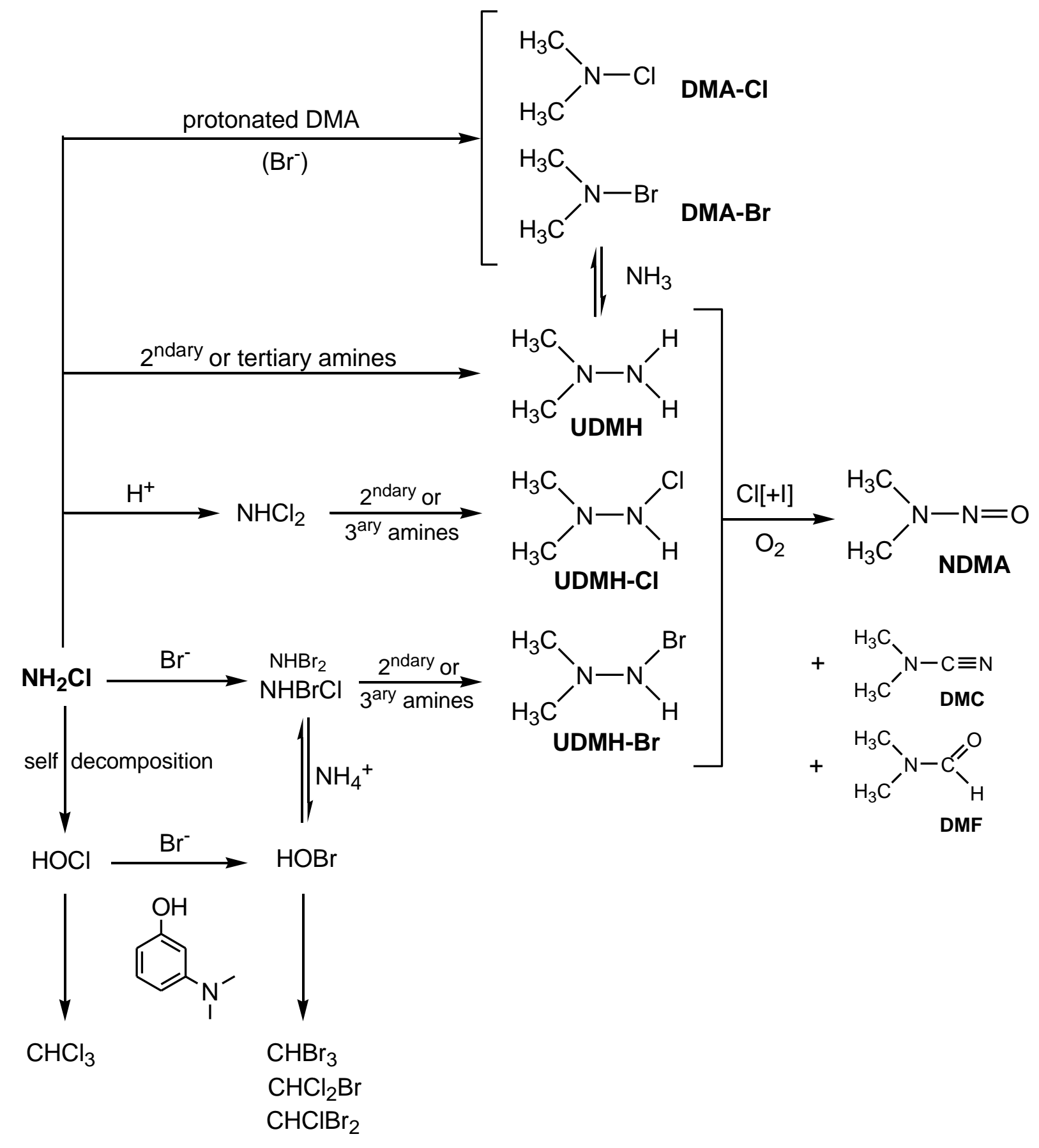

Scheme 1. Proposed pathways for NDMA formation during chloramination in the presence of bromide.

Implications for water treatment. Bromide ion is present in all natural waters and wastewaters. Hence, bromide ion may promote the formation of NDMA by chloramination of waters containing secondary and tertiary amines. This could explain the high NDMA formation potentials of natural waters or wastewaters, as compared to model waters containing similar amounts of DMA (5). The 
presence of precursor sites favoring the formation of other DBPs such as THMs, however, might compete with the formation of NDMA and thus limit the overall NDMA formation potential. The reactivity of functional groups close to precursors sites of NDMA seem to influence the proportion of halogenated DBPs and NDMA formed. Thus, the role of bromide ion in NDMA formation depends on the structural characteristics of tertiary amines.

Decomposition of monochloramine in the presence of bromide is complex and leads to many species, some of which remain unidentified. The formation of such species is of concern regarding potential health effects. The formation and identification of reactive bromamine species (e.g. bromochloramine) remain unclear and can lead to brominated DBPs of greater health concern than their chlorinated analogues.

Acknowledgments. We thank the French Ministry of Higher Education and Research (Ministère de l'Enseignement Supérieur et de la Recherche) for its financial support.

Supporting Information Available. Additional details of the materials and methods (nitrosamines and chlorinated DBPs analysis), kinetic modeling reactions, UV spectrum of the unknown product and additional figures. This information is available free of charge via the Internet at http://pubs.acs.org/.

\section{Literature Cited}

(1) Integrated Risk Information System (IRIS), N-nitrosodimethylamine; U.S. Environmental Protection Agency, Office of Research and Development (ORD), National Center for Environmental Assessment. www.epa.gov/iris/subst/0045.htm (accessed October 20, 2011).

(2) Choi, J.; Valentine, R.L. Formation of N-nitrosodimethylamine (NDMA) from reaction of monochloramine: A new disinfection by-product. Water Res. 2002, 36, 817-824. 
(3) Mitch, W.A.; Sedlak, D.L. Formation of N-nitrosodimethylamine (NDMA) from dimethylamine during chlorination. Environ. Sci. Technol. 2002, 36, 588-595.

(4) Schreiber, I.M.; Mitch, W.A. Nitrosamine formation pathway revisited: The importance of chloramine speciation and dissolved oxygen. Environ. Sci. Technol. 2006, 40, 6007-6014.

(5) Mitch, W.A.; Sedlak, D.L. Characterization and Fate of N-Nitrosodimethylamine Precursors in Municipal Wastewater Treatment Plants. Environ. Sci. Technol. 2004, 38, 1445-1454.

(6) Schmidt, C.K.; Sacher, F.; Brauch, H. Strategies for minimizing formation of NDMA and other nitrosamines during disinfection of drinking water. Proceedings of the American Water Works Association Water Quality Technology Conference, Denver, CO, 2006.

(7) Shen, R.; Andrews, S. Demonstration of 20 pharmaceuticals and personal care products (PPCPs) as nitrosamine precursors during chloramine disinfection. Water Res. 2011, 45, 944952.

(8) Le Roux, J.; Gallard, H.; Croué, J.P. Chloramination of nitrogenous contaminants (pharmaceuticals and pesticides): NDMA and halogenated DBPs formation. Water Res. 2011, $45,3164-3174$.

(9) Flury, M.; Papritz, A. Bromide in the natural environment: Occurrence and toxicity. J. Environ. Qual. 1993, 22, 747-758.

(10) Trofe, T.W.; Inman Jr, G.W.; Johnson, J.D. Kinetics of monochloramine decomposition in the presence of bromide. Environ. Sci. Technol. 1980, 14, 544-549.

(11) Vikesland, P.J.; Ozekin, K.; Valentine, R.L. Monochloramine decay in model and distribution system waters. Water Res. 2001, 35, 1766-1776.

(12) Bousher, A.; Brimblecombe, P.; Midgley, D. Kinetics of reactions in solutions containing monochloramine and bromide. Water Res. 1989, 23, 1049-1058. 
(13) Mitch, W.A.; Sharp, J.O.; Trussell, R.R.; Valentine, R.L.; Alvarez-Cohen, L.; Sedlak, D.L. Nnitrosodimethylamine (NDMA) as a drinking water contaminant: A review. Environ. Eng. Sci. 2003, 20, 389-404.

(14) Richardson, S.D.; Thruston, A.D.; Rav-Acha, C.; Groisman, L.; Popilevsky, I.; Juraev, O.; Glezer, V.; McKague, A.B.; Plewa, M.J.; Wagner, E.D. Tribromopyrrole, Brominated Acids, and Other Disinfection Byproducts Produced by Disinfection of Drinking Water Rich in Bromide. Environ. Sci. Technol. 2003, 37, 3782-3793.

(15) Richardson, S.D.; Thruston Jr, A.D.; Caughran, T.V.; Chen, P.H.; Collette, T.W.; Floyd, T.L.; Schenck, K.M.; Lykins Jr, B.W.; Sun, G.; Majetich, G. Identification of new drinking water disinfection byproducts formed in the presence of bromide. Environ. Sci. Technol. 1999, 33, $3378-3383$

(16) Luong, T.; Peters, C.; Perry, R. Influence of bromide and ammonia upon the formation of trihalomethanes under water-treatment conditions. Environ. Sci. Technol. 1982, 16, 473-479.

(17) Heller-Grossman, L.; Manka, J.; Limoni-Relis, B.; Rebhun, M. Formation and distribution of haloacetic acids, THM and TOX in chlorination of bromide-rich lake water. Water Res. 1993, 27, 1323-1331.

(18) Yang, X.; Shang, C. Chlorination Byproduct Formation in the Presence of Humic Acid, Model Nitrogenous Organic Compounds, Ammonia, and Bromide. Environ. Sci. Technol. 2004, 38, 4995-5001.

(19) Yang, X.; Shang, C.; Westerhoff, P. Factors affecting formation of haloacetonitriles, haloketones, chloropicrin and cyanogen halides during chloramination. Water Res. 2007, 41, $1193-1200$ 
(20) Thibaud, H.; De Laat, J.; Dore, M. Effects of bromide concentration on the production of chloropicrin during chlorination of surface waters. Formation of brominated trihalonitromethanes. Water Res. 1988, 22, 381-390.

(21) Muellner, M.G.; Wagner, E.D.; Mccalla, K.; Richardson, S.D.; Woo, Y.; Plewa, M.J. Haloacetonitriles vs. regulated haloacetic acids: Are nitrogen-containing DBPs more toxic? Environ. Sci. Technol. 2007, 41, 645-651.

(22) Krasner, S.W.; Weinberg, H.S.; Richardson, S.D.; Pastor, S.J.; Chinn, R.; Sclimenti, M.J.; Onstad, G.D.; Thruston Jr, A.D. Occurrence of a new generation of disinfection byproducts. Environ. Sci. Technol. 2006, 40, 7175-7185.

(23) Richardson, S.D.; Plewa, M.J.; Wagner, E.D.; Schoeny, R.; DeMarini, D.M. Occurrence, genotoxicity, and carcinogenicity of regulated and emerging disinfection by-products in drinking water: A review and roadmap for research. Mutat. Res. - Reviews in Mutation Research 2007, 636, 178-242.

(24) Disinfectants and Disinfectant Byproducts, Environmental Health Criteria 216, International Programme on Chemical Safety, World Health Organization, Geneva, 2000.

(25) Plewa, M.J.; Wagner, E.D.; Jazwierska, P.; Richardson, S.D.; Chen, P.H.; McKague, A.B. Halonitromethane drinking water disinfection byproducts: Chemical characterization and mammalian cell cytotoxicity and genotoxicity. Environ. Sci. Technol. 2004, 38, 62-68.

(26) von Gunten, U.; Salhi, E.; Schmidt, C.K.; Arnold, W.A. Kinetics and mechanisms of N nitrosodimethylamine formation upon ozonation of $\mathrm{N}, \mathrm{N}$-dimethylsulfamide-containing waters: Bromide catalysis. Environ. Sci. Technol. 2010, 44, 5762-5768. 
Chen, Z.; Yang, L.; Zhai, X.; Zhao, S.; Li, A.; Shen, J. N-nitrosamine formation during chlorination/chloramination of bromide-containing water. Water Sci. Technol.: Water Supply 2010, $10,462-471$.

(28) Choi, J.; Valentine, R.L. N-Nitrosodimethylamine Formation by Free-Chlorine-Enhanced Nitrosation of Dimethylamine. Environ. Sci. Technol. 2003, 37, 4871-4876.

(29) Mitch, W.A.; Gerecke, A.C.; Sedlak, D.L. A N-Nitrosodimethylamine (NDMA) precursor analysis for chlorination of water and wastewater. Water Res. 2003, 37, 3733-3741.

(30) Nokes, C.J. Formation of brominated organic compounds in chlorinated drinking water. In The handbook of environmental chemistry, haloforms and related compounds in drinking water; Nikolaou, A., Ed., 2003; Vol. 5, pp. 21-60.

(31) Schreiber, I.M.; Mitch, W.A. Influence of the order of reagent addition on NDMA formation during chloramination. Environ. Sci. Technol. 2005, 39, 3811-3818.

(32) Eaton, A.D., Clesceri, L.S., Greenberg, A.E., Eds. Standard Methods for the Examination of Water and Wastewater, 19th ed.; American Public Health Association/American Water Works Association/Water Environment Federation Publishers; Washington D.C., USA, 1995.

(33) US EPA Method 521: determination of nitrosamines in drinking water by solid phase extraction and capillary column gas chromatography with large volume injection and chemical ionization tandem mass spectrometry (MS/MS). EPA/600/R-05/054; U.S. Environmental Protection Agency, 2004. http://www.epa.gov/nerlcwww/m_521.pdf (accessed October 20, 2011).

(34) Le Roux, J.; Gallard, H.; Croue, J.P. Formation of NDMA by Chloramination of Nitrogenous Pharmaceuticals. Water Practice Technol. 2010, 5. 
Jafvert, C.T.; Valentine, R.L. Reaction scheme for the chlorination of ammoniacal water. Environ. Sci. Technol. 1992, 26, 577-786.

(36) Gray Jr, E.T.; Margerum, D.W.; Huffman, R.P. Chloramine equilibria and the kinetics of disproportionation in aqueous solution. ACS Symposium Series 1978, 82, 264-275.

(37) Valentine, R.L.; Brandt, K.I.; Jafvert, C.T. A spectrophotometric study of the formation of an unidentified monochloramine decomposition product. Water Res. 1986, 20, 1067-1074.

(38) Mitch, W.A.; Schreiber, I.M. Degradation of tertiary alkylamines during chlorination/chloramination: Implications for formation of aldehydes, nitriles, halonitroalkanes, and nitrosamines. Environ. Sci. Technol. 2008, 42, 4811-4817.

(39) Ichihashi, K.; Teranishi, K.; Ichimura, A. Brominated trihalomethane formation in halogenation of humic acid in the coexistence of hypochlorite and hypobromite ions. Water Res. 1999, 33, $477-483$.

(40) Heller-Grossman, L.; Idin, A.; Limoni-Relis, B.; Rebhun, M. Formation of cyanogen bromide and other volatile DBPs in the disinfection of bromide-rich lake water. Environ. Sci. Technol. 1999, 33, 932-937.

(41) Cimetiere, N.; Dossier-Berne, F.; De Laat, J. Effect of some parameters on the formation of chloroform during chloramination of aqueous solutions of resorcinol. Water Res. 2010, 44, 4497-4504.

(42) Reckhow, D.A., MacNeill, A.L., Platt, T.L., MacNeill, A.L., McClellan, J.N. Formation and degradation of dichloroacetonitrile in drinking waters. J. Water Supply Res. Technol. AQUA 2001, 50, 1-13.

(43) Hureiki, L.; Croué, J.; Legube, B. Chlorination studies of free and combined amino acids. Water Res. 1994, 28, 2521-2531. 
(44) Gallard, H.; Pellizzari, F.; Croué, J.P.; Legube, B. Rate constants of reactions of bromine with phenols in aqueous solution. Water Res. 2003, 37, 2883-2892.

(45) Weil, I.; Morris, J.C. Equilibrium studies on N-chloro compounds. II. The base strength of Nchloro dialkylamines and of monochloramine. J. Am. Chem. Soc. 1949, 71, 3123-3126.

(46) Chang, H.; Chen, C.; Wang, G. Identification of potential nitrogenous organic precursors for C, N-DBPs and characterization of their DBPs formation. Water Res. 2011, 45, 3753-3764.

SYNOPSIS TOC art.

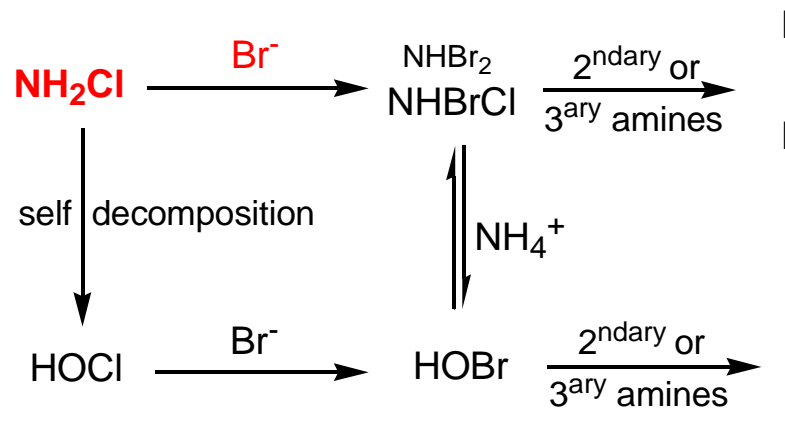<smiles>CN(C)N=O</smiles>

Brominated THMs and other halogenated DBPs 